\title{
BEATA STĘPIEŃ-ZAŁUCKA
}

University of Rzeszów, Institute of Legal SciencesDepartment of Constitutional Law and Human Rights, Poland

https://orcid.org/0000-0003-1802-680X

\section{ELECTIONS DURING A PANDEMIC}

\section{WYBORY W CZASIE PANDEMII}

Abstract: The pandemic surprised the whole world by disorganising every aspect of cultural, social, economic and political life. In Poland, its emergence overlapped with the period of the election campaign and the presidential election. As a result, the electoral calendar and the presidential election procedure itself were completely deformed. The elections ordered on 10 May 2020, despite constitutional requirements, did not allow voters to vote. Also, no state of emergency was introduced, which would justify not holding the elections. Their date was simply changed. However, the problem is that the Polish Constitution does not provide for such a procedure of "changing the election date" or, to put it differently, "ordering a new election date", without introducing a state of natural disaster. In this speach, I will explain what the pandemic is and what the fate has brought for the presidential elections in Poland, and in the final part of my speech l'll take position to them.

Keywords: elections, presidential elections, 10 May 2020, electoral rules

Streszczenie: Pandemia zaskoczyła cały świat, dezorganizując każdy aspekt życia kulturalnego, społecznego, gospodarczego, ale też politycznego. W Polsce jej wystąpienie nałożyło się na okres kampanii 
wyborczej i wyborów prezydenckich. W rezultacie zupełnie zdeformowany został kalendarz wyborczy i sama procedura wyborów prezydenckich. Zarządzone bowiem na dzień 10 maja 2020 r. wybory, mimo wymogów konstytucyjnych, nie umożliwiały oddania głosu przez wyborców. Nie został też wprowadzony stan nadzwyczajny, który usprawiedliwiałby ich nieprzeprowadzenie. Ich termin został po prostu zmieniony. Problem polega jednak na tym, że Konstytucja RP takiego trybu „zmiany terminu wyborów” bądź - ujmując to inaczej - „zarządzenia nowego terminu wyborów”, bez wprowadzenia stanu klęski żywiołowej, nie przewiduje. W niniejszym artykule przybliżę, czym jest pandemia i jak zmieniła wybory prezydenckie w Polsce, a w finalnej części wypowiedzi ustosunkuję się do nich.

Słowa kluczowe: wybory, wybory prezydenckie, wybory 10 maja 2020 r., zasady wyborcze

\section{WSTĘP}

Kiedy pod koniec 2019 r. w mediach zaczęły się pojawiać pierwsze doniesienia o nowym wirusie, większość z nas nie przykładała do tych wzmianek zbyt dużej wagi. Wirus pojawił się w mieście Wuhan w Chinach, co dla większości z nas oznaczało tysiące oddzielających nas od niego kilometrów. Jednak te tysiące kilometrów okazały się niewystarczające, by ochronić się przed nim. Szybko rozprzestrzeniający się wirus opanował bowiem nie tylko pozostałe kraje Azji, ale także Europę i cały świat.

W styczniu Światowa Organizacja Zdrowia (WHO) ogłosiła kryzysową sytuację w zakresie zdrowia publicznego. Nadała również patogenowi nazwę SARS-CoV-2, a chorobie, którą wywołuje - COVID-19. 11 marca 2020 r. ogłoszono pandemię, alarmując o rosnących zakażeniach na świecie i niezdecydowanych działaniach rządów.

Pierwszy oficjalny przypadek zachorowania w Polsce datowany jest na 4 marca 2020 r. Pojawienie się tego i kolejnych przy- 
padków zupełnie zdezorganizowało sytuację społeczną, gospodarczą, ale i polityczną w kraju, a w ramach tej ostatniej zmieniony został kalendarz wyborczy i wybory prezydenckie.

W niniejszej wypowiedzi przybliżę, czym jest pandemia i jakie są, a jakie powinny być jej następstwa prawne dla wyborów. Przedstawię konsekwencje prawne nieprzeprowadzenia wyborów 10 maja 2020 r. oraz podejmę próbę ukazania konstytucyjnych wątpliwości związanych z organizacją wyborów 28 czerwca 2020 r.

\section{CO TO JEST PANDEMIA?}

Światowa Organizacja Zdrowia definiuje pandemię jako rozprzestrzenianie się nowej choroby na całym świecie ${ }^{1}$. Termin ten wywodzi się z języka greckiego, w którym pan znaczy „wszyscy”, a mos znaczy „ludzie”. A zatem słowo „pandemia” pierwotnie oznaczało „wszyscy ludzie”. Współcześnie pojęcie to odnosi się do choroby zakaźnej, która rozprzestrzenia się na całym świecie i powoduje znaczną śmiertelność ${ }^{2}$. Przytoczona definicja wymaga głębszego wyjaśnienia. Podstawą do ogłoszenia pandemii jest bowiem sytuacja, w której zostanie udowodnione, że nowy podtyp wirusa powoduje kilka epidemii w co najmniej jednym kraju i rozprzestrzenia się na inne kraje „o spójnych wzorcach chorób wskazujących na widoczną zachorowalność i śmiertelność w co najmniej jednym segmencie populacji”3. Pandemia

1 Dane za stroną: Światowa Organizacja Zdrowia, https://www.who.int/csr/ disease/swineflu/frequently_asked_questions/pandemic/en/.

2 YAMAMOTO, T.: Pandemic Control Measures. W: Japan Medical Association Journal, 2013, t. 56, nr 1, s. 51 i n. Dane za stroną internetową: http://naosite. lb.nagasaki-u.ac.jp/dspace/bitstream/10069/33616/1/JMAJ56_51.pdf.

3 DOSHI, P.: The elusive definition of pandemic influenza. W: Bull World Health Organ, 2011, t. 89, nr 7, s. 532-538, https://www.ncbi.nlm.nih.gov/pmc/ articles/PMC3127275/, s. 14. 
jest więc chorobą epidemiczną, która rozprzestrzenia się na dużych obszarach, takich jak kontynenty, a nawet na cały świat, zaś największe jej niebezpieczeństwo płynie z faktu, iż nie da się przewidzieć z wyprzedzeniem szczepionek przeciw danemu szczepowi wirusa ${ }^{4}$.

Pandemii nie należy mylić z epidemią, która opisuje chorobę występującą w jednej populacji. Epidemia odnosi się bowiem do choroby, którą można opanować pod względem liczby osób, które mogą ulec zarażeniu, pandemia już nie. Co ciekawe, pandemie stanowią najbardziej śmiertelne zagrożenie dla ludzkości w całej historii, ponieważ pochłonęły życie większej liczby osób niż wszystkie wypadki i wojny razem wzięte $^{5}$, co ukazuje, z jak poważnym zagrożeniem mamy do czynienia.

\section{STAN EPIDEMIOLOGICZNY}

Odrywając się w tym miejscu od dywagacji na temat podstawy faktycznej wprowadzenia stanu epidemiologicznego zamiast nieokreślonego i nieznanego ustawie stanu pandemicznego czy pożądanego stanu klęski żywiołowej, 12 marca wydano rozporządzenie dotyczące wprowadzenia w Polsce stanu zagrożenia

4 Pandemic Characteristics and Response Measures, https://www.clpna.com/ wp-content/uploads/2017/09/doc_info_Sheet_Pandemic_Characteristics_and_ Response_Measures.pdf; WNĘK, J.: Pandemia grypy hiszpanki (1918-1919) w świetle polskiej prasy / The Spanish Influenza Pandemic (1918-1919) as Covered by the Polish Press. W: Archiwum Historii i Filozofii Medycyny, 2014, nr 77, file:///Users/Beata/Downloads/AHIFM_2014_v77_16to23\%20(1).pdf, s. 16-23.

${ }^{5}$ Dwa przykłady dobrze znanych pandemii to gruźlica, która jest infekcją bakteryjną przenoszoną drogą powietrzną, oraz ospa, infekcja wirusowa, która dotyka ludzi od tysięcy lat. Nowsze przykłady pandemii obejmują wirus niedoboru odporności człowieka (HIV) oraz pandemię H1N1 z 2009 r. Dane za stroną internetową: ROBERTSON, S.: What is a Pandemic? W: News Medical Life Sciences, https://www.news-medical.net/health/What-is-a-Pandemic.aspx. 
epidemicznego. Stosownie do treści art. 46 Ustawy z dnia 5 grudnia 2008 r. o zapobieganiu oraz zwalczaniu zakażeń i chorób zakaźnych u ludzi (Dz.U. z 2019 r. poz. 1239, 1495), która definiuje stan zagrożenia epidemicznego jako sytuację prawną wprowadzoną na danym obszarze w związku z ryzykiem wystąpienia epidemii w celu podjęcia określonych w ustawie działań zapobiegawczych ${ }^{6}$, wprowadzono:

1. Czasowe ograniczenia określonego sposobu przemieszczania się.

2. Czasowe ograniczenia lub zakaz obrotu i używania określonych przedmiotów lub produktów spożywczych.

3. Czasowe ograniczenia funkcjonowania określonych instytucji lub zakładów pracy.

4. Zakaz organizowania widowisk i innych zgromadzeń ludności.

\section{ZARZĄDZENIE WYBORÓW 5 LUTEGO 2020 ROKU}

Nieco wcześniej, 5 lutego, w związku z upływem kadencji urzędującego prezydenta RP, na podstawie art. 128 ust. 2 Konstytucji RP marszałek sejmu postanowieniem zarządziła wybory na urząd prezydenta Rzeczypospolitej Polskiej na dzień 10 maja 2020 r. w godz. 7.00-21.007, ${ }^{8}$. Zarządzenie to odpowiadało wymogom

6 Rozporządzenie Ministra Zdrowia z dnia 13 marca 2020 r. w sprawie ogłoszenia na obszarze Rzeczypospolitej Polskiej stanu zagrożenia epidemicznego (Dz.U. z 2020 r. poz. 433).

7 Głosowanie miało odbyć się w obwodach utworzonych za granicą w niedzielę 10 maja 2020 r. w godz. 7.00-21.00, z wyjątkiem obwodów głosowania utworzonych w krajach Ameryki Północnej i Ameryki Południowej, gdzie głosowanie miało odbyć się w sobotę 9 maja 2020 r. w godz. 7.00-21.00 czasu lokalnego.

${ }^{8}$ https://www.gov.pl/web/rumunia/wybory-prezydenckie-10-maja-2020-roku. 
art. 128 ust. 2 Konstytucji RP, w którym czytamy, że wybory prezydenta Rzeczypospolitej zarządza marszałek sejmu na dzień przypadający nie wcześniej niż na 100 dni i nie później niż na 75 dni przed upływem kadencji urzędującego prezydenta Rzeczypospolitej ${ }^{9}$. Kadencja prezydenta RP Andrzeja Dudy kończyła się 6 sierpnia, zatem wybory mogły odbyć się najpóźniej w niedzielę 24 maja. 5 lutego był więc przedostatnim dniem, w którym istniała możliwość rozpisania wyborów prezydenckich.

Po zarządzeniu wyborów w kraju wystąpiła pandemia i wprowadzono stan epidemiologiczny, co zupełnie zdeformowało kalendarz wyborczy i same wybory. W związku z wprowadzonymi ograniczeniami epidemiologicznymi 6 kwietnia 2020 r. Sejm podjął uchwałę w sprawie głosowania korespondencyjnego (uchwała o szczególnych zasadach przeprowadzania wyborów powszechnych na prezydenta Rzeczypospolitej Polskiej zarządzonych w 2020 r.). Przez kolejny miesiąc status tego aktu równał się uchwale, gdyż do przyznania jej statusu ustawy konieczna była zgoda Senatu i podpis prezydenta, a następnie publikacja w Dzienniku Ustaw. W związku z tym należy stwierdzić, że pomiędzy 6 kwietnia a 8 maja 2020 r. dokument ten nie był obowiązującym aktem prawnym ${ }^{10}$.

Przyjęcie uchwały Sejmu zmieniającej kluczowe zasady wyborcze i sposób głosowania praktycznie na miesiąc przed terminem wyborów oraz maksymalne wykorzystanie przez Senat czasu na podjęcie uchwały spowodowało, że przeprowadzenie terminów

9 GARLICKI, L.: Polskie prawo konstytucyjne. Zarys wykładu. Wydanie 6. Warszawa: Wolters Kluwer, 2019, s. 286. ISBN 978-83-8160-960-9.

10 Poselski projekt ustawy o szczególnych zasadach przeprowadzania wyborów powszechnych na Prezydenta Rzeczypospolitej Polskiej zarządzonych w 2020 r., druk 328. Szerzej na temat prac nad projektem patrz: http://www.sejm.gov.pl/ sejm9.nsf/PrzebiegProc.xsp?nr=328, akt ogłoszony 8 maja 2020 r. (Dz.U. z 2020 r. Nr 827) (dostęp: 26.05.2020). 
w pierwotnie założonym terminie stało się niewykonalne. W związku z tym 6 maja 2020 r. prezesi dwóch koalicyjnych partii rządzących wydali oświadczenie o tym, że wybory zostaną przesunięte, a marszałek sejmu wyznaczy nową datę wyborów ${ }^{11}$.

Wkrótce Państwowa Komisja Wyborcza stwierdziła, że w wyborach na urząd prezydenta Rzeczypospolitej Polskiej zarządzonych na dzień 10 maja 2020 r. nie było możliwości głosowania na kandydatów, i zgodnie z art. 293 ust. 1 Kodeksu wyborczego marszałek sejmu ma 14 dni na ponowne zarządzenie wyborów. Szef Państwowej Komisji Wyborczej poinformował także, że nie zostanie sporządzone sprawozdanie do Sądu Najwyższego ${ }^{12}$.

\section{WĄTPLIWOŚCI I KONSEKWENCJE PRAWNE DOTYCZACE NIEZORGANIZOWANIA WYBORÓW PREZYDENCKICH 10 MAJA 2020 ROKU}

Stan rzeczy zastany po 6 maja 2020 r. budzi wiele wątpliwości prawnych.

Wątpliwości te związane są przede wszystkim z samą istotą wyborów. Demokracja bowiem to nie tylko rządy ludu, ale także, a może przede wszystkim, określona forma sprawowania tej władzy przez naród. Forma ta zobowiązuje wybranych - rządzących

11 Zaskakujący zwrot akcji! Oświadczenie Kaczyńskiego i Gowina ws. wyborów prezydenckich, Dziennik.PL, 2020, 6 maja, https://wiadomosci.dziennik.pl/polityka/ artykuly/7691184,jaroslaw-kaczynski-jaroslaw-gowin-wybory-prezydenckie-sn-sad-najwyzszy-nowy-termin-niewaznosc-pis-porozumienie-marszalek-witek.html (dostęp: 15.05.2020).

12 Uchwała nr 129/2020 Państwowej Komisji Wyborczej z dnia 10 maja 2020 r. w sprawie stwierdzenia braku możliwości głosowania na kandydatów w wyborach Prezydenta Rzeczypospolitej Polskiej, https://prezydent20200510.pkw. gov.pl/prezydent20200510/statics/prezydent_2020_uchwaly/uploaded_files/1589173994_uchwala-nr-129.pdf (dostęp: 26.05.2020). 
przedstawicieli - do przestrzegania Konstytucji RP i praw człowieka, w tym prawa do bycia wybranym i wybierania ${ }^{13}$. Ponieważ jednak wybory 10 maja 2020 r. się nie odbyły, upoważnieni do głosowania zostali tego prawa, wbrew postanowieniom Konstytucji RP, pozbawieni. Innymi słowy, każdy uprawniony został bezprawnie pozbawiony konstytucyjnie przysługującego mu prawa do dokonania aktu wyboru prezydenta RP w przewidzianym przepisami Konstytucji RP terminie.

Co do zasady pozbawienie możliwości dokonania aktu wyborczego przez upoważnionych powinno bezpośrednio łączyć się z odpowiedzialnością za zaniechanie działania dokonane przez zobowiązanych do tego funkcjonariuszy publicznych, na których ciążyło wykonanie postanowienia marszałek sejmu dotyczącego zarządzenia wyborów. Paradoksalnie jednak nikogo takiego nie ma.

Wynika to z faktu, że art. 102 ustawy nazywanej Tarcza 2.0 wyłączał stosowanie w czasie epidemii przepisów Kodeksu wyborczego (k. wyb.) ${ }^{14}$ i odebrał Państwowej Komisji Wyborczej kompetencje w zakresie drukowania kart wyborczych i określania ich wzorów (art. 307 k. wyb. ${ }^{15}$ ), a nie przyjęto nowej ustawy określającej uprawnionego do tego ${ }^{16}$.

13 TULEJA, P.: Komentarz do art. 2. W: Safjan, M., Bosek, L. (red.), Konstytucja RP. Komentarz. Tom 1. Komentarz do art. 1-86. Wydanie 1. Warszawa: C.H. Beck, 2016, s. 237; Wyrok Trybunału Konstytucyjnego z dnia 25 listopada 1997 r., K 26/97.

14 Ustawa z dnia 5 stycznia 2011 r. - Kodeks wyborczy - ustawa regulująca prawo wyborcze w Polsce (Dz.U. z 2011 r. Nr 21, poz. 112).

15 Szerzej na temat tej kompetencji Państwowej Komisji Wyborczej: RYMARZ, F.: Komentarz do art. 307. W: Czaplicki, K.W., Dauter, B. i in., Kodeks wyborczy. Wydanie 1, Warszawa: Wolters Kluwer, 2014, s. 658.

16 Ustawa z dnia 16 kwietnia 2020 r. o szczególnych instrumentach wsparcia w związku z rozprzestrzenianiem się wirusa SARS-CoV-2 (Dz.U. z 2020 r., poz. 695); co ważne, Tarcza 2.0 uniemożliwiała także zrealizowanie obowiązku publikacji informacji o obwodach do głosowania i komisjach Państwowej Komisji Wyborczej na 30 dni przed dniem głosowania, a o terminie, godzinach głosowania itp. - najpóźniej 21 dni przed dniem wyborów. 
W praktyce zatem decyzja drugiej osoby w państwie, bo taki status posiada marszałek sejmu, co wynika z faktu, że nie mamy urzędu wiceprezydenta, nie została wykonana. Nie został też wprowadzony stan klęki żywiołowej, który mógłby uzasadnić niewykonanie takiej decyzji.

W ocenie tej sytuacji należy wziąć pod uwagę, że marszałek sejmu ma szczególną pozycję ustrojową, w związku z czym podejmowane przez niego akty prawne mają szczególny status i o ich wykonaniu przesądza Konstytucja RP. Innymi słowy, w moim przekonaniu zarządzenie marszałka sejmu co do terminu wyborów jest materią podlegającą bezwzględnemu wykonaniu i żadna ustawa zwykła nie jest w stanie zatrzymać wykonania tego postanowienia. Wyjątkiem jest wprowadzenie jednego ze stanów nadzwyczajnych i to jest jedyny przypadek, kiedy to możliwe jest niezorganizowanie wyborów zarządzonych przez marszałka. Kluczowa dla takiego uznania jest treść postanowienia art. 128 ust. 2, który brzmi „Wybory Prezydenta Rzeczypospolitej zarządza marszałek sejmu na dzień przypadający nie wcześniej niż na 100 dni i nie później niż na 75 dni przed upływem kadencji urzędującego Prezydenta Rzeczypospolitej”. Zwrot „zarządza” jest jednoznaczny i wiąże się po pierwsze z obowiązkiem zarządzenia wyborów przez marszałka, a po drugie - z obowiązkiem jego wykonania zgodnie z art. 7 Konstytucji (organy władzy publicznej działają na podstawie i w granicach prawa, a tym najwyższym prawem jest Konstytucji RP). W związku z tym w praktyce muszą obowiązywać przepisy, które to umożliwią. Uzupełnieniem powyższego jest fakt, że to ustawa ma obowiązek dostosować się do postanowień Konstytucji RP i dążyć do jej wykonania, a nie jej niewykonania, jak to jest przypadku przybliżonych regulacji ustawy Tarcza 2.0.

Przedstawiane powyżej argumenty prowadzą do jednoznacznego wniosku: postanowienia Tarczy 2.0 w omawianym 
zakresie są niekonstytucyjne. Zamiarem działania Sejmu poprzez wprowadzenie postanowień art. 102 było obejście prawa, a takie działanie nie korzysta z ochrony prawnej i powinno podlegać pozbawieniu mocy prawnej przez Trybunał Konstytucyjny (TK). Pozostawienie luki prawnej miało na celu celowe i świadome niewykonanie przepisów Konstytucji RP (na taką ocenę wpływa niepozostawienie odpowiedniego czasu na przygotowanie i uchwalenie nowych regulacji) dotyczących wykonania zarządzenia marszałka o wyborze prezydenta RP.

Konkludując tę część rozważań, należy stwierdzić, że w rezultacie obowiązywania Tarczy 2.0 i braku nowej ustawy powstała luka w przepisach prawa, co sprawiło, że nie było nikogo odpowiedzialnego za drukowanie kart.

Niezależnie jednak od istnienia luki prawnej - braku uprawnionego do drukowania kart - karty były drukowane, a dane wrażliwe wyborców zostały przekazane. Poczta Polska podjęła się przygotowań do przeprowadzenia wyborów, które według doniesień prasowych finalnie kosztowały $69 \mathrm{mln} z \mathfrak{ł}^{17}$. A przypomnijmy, że działania te nie posiadały podstawy prawnej, co oznacza że zgodnie z art. 198 Konstytucji grozi za nie odpowiedzialność przed Trybunałem Stanu. Poza tym w grę wchodzi także odpowiedzialność karna. Z jednej bowiem strony drukowanie kart i przekazanie danych wrażliwych bez podstawy prawnej nosi znamiona przestępstwa karnego określonego w art. 231 Kodeksu karnego (k.k.), dotyczącego przekroczenia uprawnień przez funkcjonariusza publicznego, które zagrożone jest karą więzienia do lat trzech, z drugiej zaś strony nie można pominąć faktu niegospodarności środ-

17 Wiemy, ile kosztowały wybory 10 maja. GIGANTYCZNA kwota. W: Super Express, 2020, 26 maja, https://www.se.pl/wiadomosci/polityka/wiemy-ile-kosztowaly-wybory-10-maja-gigantyczna-kwota-aa-DKyR-PSeo-nmbE.html (dostęp: 26.05.2020). 
kami publicznymi, które to działanie zagrożone jest karą więzienia od trzech miesięcy do lat pięciu (art. 296 k.k.) ${ }^{18}$.

\section{ZARZAQDZENIE I PRZEPROWADZENIE WYBORÓW 28 CZERWCA 2020 ROKU}

W dalszej kolejności, jak zadeklarowano, stosownie do treści art. 128 ust. 2 Konstytucji RP, art. 293 § 2 k. wyb. oraz 15 ust. 1 Ustawy z dnia 2 czerwca 2020 r. o wyborach korespondencyjnych $^{19}$, 3 czerwca 2020 r. marszałek sejmu wyznaczyła termin wyborów na 28 czerwca (tego dnia miała odbyć się pierwsza tura, natomiast druga - 12 lipca $)^{20}$.

Przyjęcie wspomnianej regulacji pogłębia dotychczasowe wątpliwości.

W moim przekonaniu bowiem marszałek sejmu nie ma prawnej możliwości zmiany terminu wyborów, ponieważ takiej zmiany nie przewiduje Konstytucja RP, a do jej postanowień nie stosujemy wykładni rozszerzającej. Raz zarządzone wybory muszą zostać przeprowadzone i nie można ustawą zmienić postanowień Konstytucji RP w tym zakresie. Innymi słowy, gdyby ustrojodawca chciał przyznać marszałkowi sejmu uprawnienie do zmiany

18 Ustawa z dnia 6 czerwca 1997 r. - Kodeks karny (Dz.U. z 1997 r. Nr 88 poz. 553).

19 Ustawa z dnia 2 czerwca 2020 r. o szczególnych zasadach organizacji wyborów powszechnych na Prezydenta Rzeczypospolitej Polskiej zarządzonych w 2020 r. z możliwością głosowania korespondencyjnego (Dz.U. z 2020 r. poz. 979).

20 Jeśli na terytorium Polski ogłoszono stan epidemii, marszałek sejmu może zarządzić zmianę terminu wyborów wyznaczonego w wydanym wcześniej postanowieniu. Nowy termin wyborów określony przez marszałka sejmu musi odpowiadać terminom przeprowadzenia wyborów prezydenckich określonym w Konstytucji. Ustawa z dnia 2 czerwca 2020 r. o szczególnych zasadach organizacji wyborów powszechnych na Prezydenta Rzeczypospolitej Polskiej zarządzonych w 2020 r. z możliwością głosowania korespondencyjnego (Dz.U. z 2020 r. poz. 979). 
terminu wyborów, to by to zrobił. Ustrojodawca wprowadził natomiast instytucję stanów nadzwyczajnych, która wiąże się z określonymi konsekwencjami prawnymi, a jedną z nich jest zarządzenie nowych wyborów przez marszałka sejmu.

Wątpliwości co do konstytucyjności obowiązujących przepisów dotyczących wyborów prezydenckich wiążą się także z terminem wprowadzania zmian w przepisach wyborczych.

Artykuł 2 Konstytucji RP zobowiązuje ustawodawcę do zachowania standardu demokratycznego zwanego ciszą ustawodawczą. Standard ten wymaga, aby wszystkie istotne reguły prawa wyborczego były znane co najmniej na 6 miesięcy przed zarządzeniem wyborów. Naruszenie art. 2 Konstytucji ma bezpośredni wpływ na wynik wyborów, narusza zasady swobodnej rywalizacji sił politycznych w państwie demokratycznym, zasadę pewności prawa, zasadę ochrony maksymalnie ukształtowanych ekspektatyw i zasady poprawnej legislacji (mówi o tym wyrok Trybunału Konstytucyjnego, sygn. Kp 3/09)21. W tym kontekście szczególne obawy rodzi fakt, że obywatele nie mieli zbyt wiele czasu na naukę sposobu, w jaki można oddać głos korespondencyjne. Poza tym swoisty niepokój wzbudza także doręczenie pakietu wyborczego na czas w tak szybkim tempie przez spółkę prawa handlowego (Pocztę Polską).

A propos zasad poprawnej legislacji - nie można nie zwrócić uwagi na fakt, że ustawa dotycząca zasad organizacji wyborów prezydenckich weszła w życie w dniu ogłoszenia. Co oznacza, że vocatio legis nie istniało, a przecież to jedna z podstawowych wytycznych zasad poprawnej legislacji (o czym jest mowa w wyroku Trybunału Konstytucyjnego z 20 grudnia 1999 r., sygn. K 4/99 oraz w wyroku z 16 września 2003 r., sygn. K 55/02). Trybunał

21 Wyrok Trybunału Konstytucyjnego z dnia 20 lipca 2011 r., K 9/11, OTK-A 2011/6/61. 
Konstytucyjny wielokrotnie w swoim orzecznictwie podkreślał jego wagę i znaczenie w demokratycznym państwie prawa, uznając, że odpowiedni termin spoczywania ustawy pozwala na zapoznanie się z nowymi normami i dostosowanie do nich. Dzięki czemu możliwe jest budowanie zaufania obywateli do państwa i rzetelności stanowionego przez nie prawa.

Zresztą o to budowanie zaufania obywateli do państwa jest trudno, w sytuacji gdy zasadnicza ustawa dotycząca przeprowadzenia wyborów na najwyższy urząd w państwie zostaje uchwalona w „trybie więcej niż pilnym”, tj. w 2 godziny i 43 minuty z licznymi naruszeniami prawa w $\mathrm{tle}^{22}$.

Dalsze wątpliwości konstytucyjne pojawiają się wobec realizacji zasad wyborczych. Artykuł 127 ust. 1 Konstytucji RP stanowi: „Prezydent Rzeczypospolitej jest wybierany przez Naród w wyborach powszechnych, równych, bezpośrednich i w głosowaniu tajnym". Wcielenie w życie powyższych zasad wyborczych warunkuje realizację kolejnego przymiotnika wyborczego, nieokreślonego expressis verbis w Konstytucji RP, jednak w pełni obowiązującego, a mianowicie zasady wolnych wyborów ${ }^{23}$.

W odniesieniu do wspomnianych zasad wyborczych obawy budzi pytanie, czy pakiety dotrą na czas i przede wszystkim czy wszyscy uprawnieni do głosowania będą mieli możliwość oddania głosu. Wątpliwości te są zasadne, gdyż już na etapie zbierania podpisów

22 Szerzej na ten temat: UZIĘBŁO, P.: Jak nie stanowić prawa, czyli uwagi na marginesie procesu uchwalania Ustawy z dnia 6 kwietnia 2020 r. o szczególnych zasadach przeprowadzania wyborów powszechnych na Prezydenta Rzeczypospolitej Polskiej zarządzonych w 2020 r., https://palestra. pl/pl/e-palestra/17/2020/jak-nie-stanowic-prawa-czyli-uwagi-na-marginesieprocesu-uchwalania-ustawy-z-6.04.2020-r.-o-szczegolnych-zasadachprzeprowadzania-wyborow-powszechnych-na-prezydenta-rzeczypospolitejpolskiej-zarzadzonych-w-2020-r. (dostęp: 26.05.2020).

${ }^{23}$ FRYDRYCH, A., SOBCZYK, M. Orzecznictwo Trybunału Konstytucyjnego w sprawach wyborczych. Wydanie 1. Toruń: TNOIK, 2011, s. 207. 
poparcia nie wszyscy kandydaci mieli takie same szanse ${ }^{24}$. Ponadto już wiadomo, na tydzień przed wyborami, iż mimo że poza granicami naszego kraju zarejestrowała się rekordowa liczba wyborców (ponad 300 tys.), to w praktyce również rekordowa liczba została tego prawa pozbawiona. Pandemia trwająca w innych krajach uniemożliwia polskim obywatelom realizację ich prawa wyborczego. To bowiem, czy wybory odbywają się w danym kraju czy nie, zależy tylko i wyłącznie od decyzji jego władz. A obecnie niektóre z krajów, w których żyje PoIonia - Kuwejt, Peru i Chile - z powodu pandemii nie wyraziły zgody na przeprowadzenie wyborów. Ponadto są państwa, takie jak Stany Zjednoczone, Wielka Brytania czy Niemcy, które wyraziły zgodę tylko i wyłącznie na wybory korespondencyjne ${ }^{25}$. W innych krajach fizyczne oddanie głosu (np. ze względu na niestandardowe działanie poczty) jest niemożliwe albo utrudnione w związku z pandemią. Mowa tu przede wszystkim o krajach Ameryki Południowej i Afryki ${ }^{26}$.

Zresztą należy zauważyć, że wyłączenie spod głosowania dotyczy nie tylko obywateli polskich przebywających za granicą, z taką sytuacją mamy także do czynienia w Polsce. Wynika to faktu, iż osoby, które znajdą się na kwarantannie, po 26 czerwca nie miały możliwości oddania głosu ${ }^{27}$.

24 Szerzej na ten temat: Wybory prezydenckie: Poznaliśmy kalendarz wyborczy. Ile czasu na zbieranie podpisów? W: Wprost, 2020, 3 czerwca, https://zdrowie. wprost.pl/koronawirus/10331225/wybory-prezydenckie-poznalismy-kalendarz-wyborczy-ile-czasu-na-zbieranie-podpisow.html (dostęp: 5.06.2020).

25 https://www.gov.pl/web/dyplomacja/glosowanie-za-granica.

26490 tys. ofiar COVID-19 na świecie. WHO krytykuje Szwecję, https://www. rmf24.pl/raporty/raport-koronawirus-z-chin/najnowsze-fakty/news-490-tys-ofiarcovid-19-na-swiecie-who-krytykuje-szwecje-rela,nld,4576419; Najgorsza doba w Afryce od początku epidemii, Rzeczpospolita, 2020, 31 maja, https://www.rp.pl/ Koronawirus-SARS-CoV-2/200539943-Najgorsza-doba-w-Afryce-od-poczatku-epidemii.html.

27 Wybory 2020. Jak wygląda głosowanie osób skierowanych na kwarantannę?, https://www.medonet.pl/koronawirus/koronawirus-w-polsce,wybory-2020--jak-wyglada-glosowanie-osob-skierowanych-na-kwarantanne-,artykul,67807431.html. 
Sytuacja gdy upoważnieni do głosowania nie mają możliwości skorzystać z tego prawa, a jedyną formą głosowania jest głosowanie korespondencyjne albo możliwość oddania głosu jest nader utrudniona, godzi wprost w zasadę powszechności wyborów zawartą w Konstytucji RP. Dodatkowo zagrożenie przymiotników wyborczych łączy się z kwestią osobistego uzupełnienia karty do głosowania przez wyborcę i tego, iż treść aktu głosowania nie jest dostępna dla osób trzecich.

Wobec powyższych ustaleń należy stwierdzić, że przedmiotowa regulacja godzi dodatkowo $w$ art. 4 Konstytucji28. Wynika to z faktu, iż zasada suwerenności narodu oznacza m.in., że prawo wyborcze powinno być tak „[...] konstruowane, aby stwarzać wyborcom jak największe możliwości udziału w wyborach celem wskazania przedstawicieli, którzy w ich imieniu będą sprawować władzę", jeżeli natomiast część uprawnionych do głosowania nie ma prawnej ani faktycznej możliwości oddania głosu, to takie wybory nie mogą zostać uznane za spełniające warunki konstytucyjne i ustawowe, a tym samym za ważne ${ }^{29}$.

\section{STAN KLĘSKI ŻYWIOŁOWEJ}

Powyższych problemów i wątpliwości udałoby się uniknąć, gdyby w Polsce został wprowadzony stan klęski żywiołowej. Wymaga przypomnienia, że jest to jeden ze stanów nadzwyczajnych określonych w Konstytucji RP. Wprowadza się go, podobnie jak pozostałe stany nadzwyczajne, tj. wojenny i wyjątkowy, w sytuacjach szczególnych zagrożeń, gdy zwykłe środki konstytucyjne

28 Szerzej na ten temat: DZIAŁOCHA, K.: Komentarz do art. 4 Konstytucji RP. W: Konstytucja Rzeczypospolitej Polskiej. Komentarz, wydanie drugie uzupełnione. Warszawa: Wydawnictwo Sejmowe, 2016, s. 176-229.

29 Wyrok Trybunału Konstytucyjnego z dnia 20 lipca 2011 r., K 9/11. 
są niewystarczające (art. 228 ust. 1 Konstytucji RP). Jego wprowadzenie jest niezwykle istotne z punktu widzenia ochrony praw jednostki i zapewniania praworządnego funkcjonowania organów władzy publicznej. Niekiedy bowiem nie sposób przewidzieć wydarzeń nadzwyczajnych, które mogą zdarzyć się nawet w najbardziej demokratycznym państwie. Ważne jednak, by system był na nie przygotowany ${ }^{30}$.

Szczegółową przesłanką do wprowadzenia stanu klęski żywiołowej jest zapobieżenie lub usunięcie skutków katastrof naturalnych lub awarii technicznych noszących znamiona klęski żywiołowej (art. 232 Konstytucji RP). Z regulacji tej możemy wywnioskować, że przesłanki te mają dwojaki charakter, po pierwsze - prewencyjny (zapobieżenie katastrofom), po drugie zaś ratowniczy (usunięcie ich skutków) 31 .

W świetle orzecznictwa Trybunału Konstytucyjnego klęska żywiołowa to wszelkiego rodzaju zdarzenia żywiołowe, które zagrażają bezpieczeństwu, życiu lub mieniu większej liczby osób albo też mogą wywołać poważne zakłócenia gospodarki narodowej, dla których zwalczania niezbędna jest zorganizowana akcja społeczna. W przytoczonej definicji uwagę zwraca żywiołowość zjawiska, a więc jego absolutna niezależność od woli i świadomości człowieka, a także rozmiar, którego skutkiem jest zagrożenie dotyczące większej liczby osób. W tym samym orzeczeniu

30 CZURA, M.: Stany Nadzwyczajne. Wyrok TK S 1/01. W: ZUBIK, M. (red.), Konstytucja w tezach orzeczniczych Trybunału Konstytucyjnego i wybranych sądów. Wydanie 1. Warszawa: C.H. Beck, 2008, s. 820; CIEKANOWSKI, Z., STACHOWIAK, Z.: Klęski żywiołowe jako przesłanki sytuacji nadzwyczajnych / Natural disasters as the rationale behind emergencies. W: Zeszyty Naukowe Uniwersytetu Przyrodniczo-Humanistycznego w Siedlcach, 2012, nr 95, seria: Administracja, s. 375.

31 WINCZOREK, P.: Komentarz do Konstytucji Rzeczypospolitej Polskiej z dnia 2 kwietnia 1997 r. Wydanie 2 rozszerzone. Warszawa: Liber, 2000, s. 437; PROKOP, K.: Stany nadzwyczajne w Konstytucji Rzeczypospolitej Polskiej z dnia 2 kwietnia 1997 r. Wydanie 1. Białystok: Temida 2, 2005, s. 106-112. 
Trybunał dla lepszego zgłębienia istoty klęski żywiołowej odwołał się do potocznego rozumienia tego terminu, wskazując, że jest to „zniszczenie, katastrofa wywołana działaniem sił przyrody, którego skutki dotykają szeroki krąg osób"32.

W świetle postanowienia art. 3 ust. 1 pkt. 2 Ustawy o stanie klęski żywiołowej katastrofa naturalna to zdarzenie związane z działaniem sił natury, w szczególności wyładowania atmosferyczne, wstrząsy sejsmiczne, silne wiatry, intensywne opady atmosferyczne, długotrwałe występowanie ekstremalnych temperatur, osuwiska ziemi, pożary, susze, powodzie, zjawiska lodowe na rzekach i morzu oraz jeziorach i zbiornikach wodnych, masowe występowanie szkodników, chorób roślin lub zwierząt albo chorób zakaźnych ludzi albo też działanie innego żywiołu ${ }^{33}$.

Stan klęski żywiołowej wprowadza Rada Ministrów na czas oznaczony, nie dłuższy niż 30 dni, na części albo na całym terytorium państwa. Przedłużenie tego stanu może nastąpić za zgodą Sejmu. Przy czym należy odnotować, że pomimo iż stan klęski żywiołowej ma datę graniczną, to jego powtórzenie jest możliwe.

32 Wyrok Trybunału Konstytucyjnego z dnia 6 marca 2001 r., sygn. K 30/00. Zob. także uwagi w tym zakresie: KAZIMIERCZUK, M.: Zasady funkcjonowania państwa podczas stanu klęski żywiołowej w III RP. W: Studia Prawnoustrojowe, 2005, nr 4, s. 86 i n. Szerzej na temat definicji klęsk żywiolowych: WŁODARCZYK, E.: Klęska żywiołowa lub ekologiczna, https://repozytorium.amu.edu.pl/bitstream/10593/12709/1/ Wlodarczyk\%20E_Kleska_zywiolowa_ekologiczna_pop.pdf.

33 Ustawa z dnia 18 kwietnia 2002 r. o stanie klęski żywiołowej (Dz.U. z 2002 r. Nr 62 poz. 558), Wyrok Naczelnego Sądu Administracyjnego z dnia 31 maja 2016 r., FSK 1178/14, Legalis nr 1485784. Warto jednak wskazać, że współcześnie w nauce coraz częściej podkreśla się, że określoną w art. 3 ust. 2 Ustawy o stanie klęski żywiołowej „katastrofę naturalną lub awarię techniczną może wywołać również zdarzenie bądź zdarzenia w cyberprzestrzeni oraz działania o charakterze terrorystycznym". W praktyce oznacza to, że mogą one być także następstwem działań ludzkich. DOMAŃSKA, A.: Skutki wprowadzenia stanu klęski żywiołowej. W: Ekspertyzy i Opracowania, 2019, nr 91, s. 3, https://www.nist.gov.pl/files/zalacznik/1575972259_EiOP\%20nr\%2091_2019.pdf. 
Zgodę na nie wyraża Sejm w drodze uchwały, bezterminowo ${ }^{34}$. Wprowadzenie stanu klęski żywiołowej wiąże się z tym, że:

$\Rightarrow$ może nastąpić zmiana zasad działania organów władzy publicznej oraz zakresu, w jakim mogą zostać ograniczone wolności i prawa człowieka i obywatela w czasie jego trwania, co określa ustawa,

$\Rightarrow$ ustawa może określić podstawy, zakres i tryb wyrównywania strat majątkowych wynikających z ograniczenia w czasie jego trwania wolności oraz praw człowieka i obywatela,

$\Rightarrow$ działania podjęte w wyniku wprowadzenia stanu klęski żywiołowej muszą odpowiadać stopniowi zagrożenia i powinny zmierzać do jak najszybszego przywrócenia normalnego funkcjonowania państwa,

$\Rightarrow$ w czasie jego trwania nie mogą być zmienione: Konstytucja, ordynacje wyborcze do Sejmu, Senatu i organów samorządu terytorialnego, ustawa o wyborze prezydenta Rzeczypospolitej oraz ustawy o stanach nadzwyczajnych,

$\Rightarrow$ w czasie jego trwania oraz w ciągu 90 dni po jego zakończeniu nie może być skrócona kadencja Sejmu, przeprowadzane referendum ogólnokrajowe, nie mogą być zorganizowane wybory do Sejmu, Senatu, organów samorządu terytorialnego oraz wybory prezydenta Rzeczypospolitej, a kadencje tych organów ulegają odpowiedniemu przedłużeniu. Wybory do organów samorządu terytorialnego są możliwe tylko tam, gdzie nie został wprowadzony stan klęski żywiołowej (art. 228 Konstytucji RP) ${ }^{35}$.

34 WINCZOREK, P.: dz. cyt., s. 437.

35 Szerzej na ten temat: BRYK, T.: Przegląd regulacji stanów nadzwyczajnych w przepisach Konstytucji RP. W: Przegląd Prawa Konstytucyjnego, 2011, nr 1, s. $225 \mathrm{i}$. 
Zakończenie stanu klęski żywiołowej może nastąpić w trojaki sposób. Pierwszym jest upływ czasu, na jaki został on ogłoszony, drugim wydanie rozporządzenia Rady Ministrów przed upływem tego terminu, jeśli ustaną przyczyny jego wprowadzenia, a także wówczas, gdy Sejm nie wyrazi zgody na jego przedłużenie. Rozporządzenie znoszące stan klęski żywiołowej podlega ogłoszeniu w Dzienniku Ustaw oraz podaje się je do publicznej wiadomości36.

\section{PODSUMOWANIE}

Rekapitulując powyższe rozważania, należy stwierdzić, że przeprowadzanie wyborów w czasie trwania pandemii w obecnym kształcie narusza wiele spośród postanowień Konstytucji RP. Rodzi równocześnie zapytania o bierność władz, które nie wprowadziły stanu klęski żywiołowej, co w obecnym czasie jest uzasadnione i pożądane. Taki stan przedłużyłby kadencję urzędującego prezydenta RP i pozwolił na swobodne przeprowadzenie wyborów, gdy zagrożenie dla wyborców byłoby mniejsze.

Równolegle należy pamięć, że ostatnie wybory prezydenckie nie tylko miały zostać po prostu przeprowadzone, ale musiały zostać uznane przez Sąd Najwyższy za ważne, tj. musiały spełnić demokratyczne standardy ${ }^{37}$, których żadna ustawa Tarcza 2.0 czy inna nie była w stanie prawnie wyłączyć. Mieliśmy natomiast do czynienia z sytuacją, kiedy już było wiadomo, że niektóre z krajów, w których żyje Polonia, nie wyraziły zgody na przeprowadzenie wyborów, a w innych fizyczne ich zorganizowanie bądź oddanie głosu było niemożliwe albo znacznie utrudnione w związku z pandemią.

\footnotetext{
36 DOMAŃSKA, A.: dz. cyt., s. 3.

37 GARLICKI, L.: dz. cyt., s. 287.
} 
Dodatkowo pojawiają się wątpliwości związane z bardzo krótkim czasem na rozpowszechnienie wiedzy dotyczącej nowych regulacji wyborczych i z dostarczeniem oraz przekazywaniem pakietów wyborczych.

Poza tym pojawia się także kolejna wątpliwość dotycząca samej pandemii - czy warto narażać głosujących oraz członków komisji wyborczych na zachorowanie za sprawą kontaktu z osobą zarażoną, co może prowadzić do utraty zdrowia, a nawet życia.

Pozostaje jeszcze kwestia wizerunku Polski na arenie międzynarodowej - zarządzenie wyborów, nieprzeprowadzenie ich i wątpliwości konstytucyjne co do ich organizacji powodują, że jako podmiot prawa tracimy wiarygodność.

To wszystko sprawia, że finalnie wniosek może być tylko jeden - te wybory nie powinny zostać zarządzone ani nie powinny się odbyć. Powinien natomiast zostać ogłoszony stan klęski żywiołowej.

Odrębną kwestią natomiast jest możliwość ubiegania się przez każdego upoważnionego wyborcę, który nie mógł zagłosować zgodnie z konstytucyjnie przysługującym mu prawem do wyboru prezydenta RP w dniu 10 maja 2020 r., o odszkodowanie z tytułu przekazania przez osoby nieuprawnione, działające bez podstawy prawnej, danych wrażliwych spółce prawa handlowego - Poczcie Polskiej w związku z wyborami zarządzonymi na dzień 10 maja 2020 r. $^{38}$

38 Rozporządzenie z dnia 4 maja 2016 r., 2016/679 o ochronie danych osobowych (RODO) DZ.U. UE.L. 2016.119.1. 


\section{BIBLIOGRAFIA:}

BRYK, T.: Przegląd regulacji stanów nadzwyczajnych w przepisach Konstytucji RP. W: Przegląd Prawa Konstytucyjnego, 2011, nr 1, s. 225 i n. ISBN: 978-83-7611-944-1.

CIEKANOWSKI, Z., STACHOWIAK Z.: Klęski żywiołowe jako przesłanki sytuacji nadzwyczajnych / Natural disasters as the rationale behind emergencies. W: Zeszyty Naukowe Uniwersytetu Przyrodniczo-Humanistycznego w Siedlcach, 2012, nr 95, seria: Administracja, s. 375.

CZURA, M.: Stany Nadzwyczajne. Wyrok TK S 1/01. W: Zubik, M. (red.), Konstytucja w tezach orzeczniczych Trybunału Konstytucyjnego i wybranych sądów. Wydanie 1. Warszawa: C.H. Beck, 2008, s. 820. ISBN 978-837-483-7422.

DZIAŁOCHA, K.: Komentarz do art. 4 Konstytucji RP. W: Konstytucja Rzeczypospolitej Polskiej. Komentarz. Wydanie 2 uzupełnione. Warszawa: Wydawnictwo Sejmowe, 2016, s. 176-229. ISBN 9788-376-66-44-91.

DOMAŃSKA, A.: Skutki wprowadzenia stanu klęski żywiołowej. W: Ekspertyzy i Opracowania, 2019, nr 91, s. 3, https://www.nist.gov.pl/ files/zalacznik/1575972259_EiOP\%20nr\%2091_2019.pdf (dostęp: 2.05.2020).

DOSHI, P.: The elusive definition od pandemic influenza. W: Bull World Health Organ, 2011, t. 89, nr 7, s. 532-538, https://www.ncbi.nlm. nih.gov/pmc/articles/PMC3127275/, s. 14 (dostęp: 2.05.2020).

FRYDRYCH, A., SOBCZYK, M.: Orzecznictwo Trybunału Konstytucyjnego w sprawach wyborczych. Wydanie 1. Toruń: TNOIK, 2011, s. 207. ISBN 978-83-72-856326.

GARLICKI, L.: Polskie prawo konstytucyjne. Zarys wykładu. Wydanie 6. Warszawa: Wolters Kluwer, 2019, s. 286. ISBN 978-83-8160-960-9.

KAZIMIERCZUK, M.: Zasady funkcjonowania państwa podczas stanu klęski żywiołowej w III RP. W: Studia Prawnoustrojowe, 2005, nr 4.

RYMARZ, F.: Komentarz do art. 307. W: Czaplicki, K.W., Dauter, B. i in., Kodeks wyborczy. Wydanie 1. Warszawa: Wolters Kluwer, 2014, s. 658. ISBN 978-83-264-3277-4.

TULEJA, P.: Komentarz do art. 2. W: Safjan, M., Bosek, L. (red.), Konstytucja RP. Komentarz. Tom 1. Komentarz art. 1-86. Wydanie 1. Warszawa: C.H. Beck, 2016, s. 237. ISBN 978-83-255-7365-2. 
UZIĘBŁO, P.: Jak nie stanowić prawa, czyli uwagi na marginesie procesu uchwalania Ustawy z 6 kwietnia 2020 r. o szczególnych zasadach przeprowadzania wyborów powszechnych na Prezydenta Rzeczypospolitej Polskiej zarządzonych w 2020 r., https:// palestra.pl/pl/e-palestra/17/2020/jak-nie-stanowic-prawa-czyliuwagi-na-marginesie-procesu-uchwalania-ustawy-z-6.04.2020-r.o-szczegolnych-zasadach-przeprowadzania-wyborow-powszechnych-na-prezydenta-rzeczypospolitej-polskiej-zarzadzonych-w2020-r. (dostęp: 26.05.2020).

WINCZOREK, P.: Komentarz do Konstytucji Rzeczypospolitej Polskiej z dnia 2 kwietnia 1997 r. Wydanie 2 rozszerzone. Warszawa: Liber, 2000, s. 473. ISBN 978-83-72-060-822.

WNĘK, J.: Pandemia grypy hiszpanki (1918-1919) w świetle polskiej prasy / The Spanish Influenza Pandemic (1918-1919) as Covered by the Polish Press, Archiwum Historii i Filozofii Medycyny, 2014, nr 77, file://Users/Beata/Downloads/AHIFM_2014_v77_16to23\%20 (1).pdf, s. 16-23, ISSN 0860-1844.

YAMAMOTO, T.: Pandemic Control Measures. W: Japan Medical Association Journal, 2013, t. 56, nr 1, s. 51 i n., http://naosite.lb.nagasaki-u.ac.jp/dspace/bitstream/10069/33616/1/JMAJ56_51.pdf (dostęp: 2.05.2020).

\section{Źródła internetowe}

Pandemic Characteristics and Response Measures, https://www.clpna. com/wp-content/uploads/2017/09/doc_info_Sheet_Pandemic_ Characteristics_and_Response_Measures.pdf.

PROKOP, K.: Stany nadzwyczajne w Konstytucji Rzeczypospolitej Polskiej z dnia 2 kwietnia 1997 r. Wydanie 1. Białystok: Temida 2, 2005, s. 106-112. ISBN 9788389620071.

ROBERTSON: What is a Pandemic? W: News Medical Life Sciences, https://www.news-medical.net/health/What-is-a-Pandemic.aspx (dostęp: 2.05.2020).

WŁODARCZYK, E.: Klęska żywiołowa lub ekologiczna, https://repozytorium.amu.edu.pl/bitstream/10593/12709/1/Wlodarczyk\%20E_Kleska_zywiolowa_ekologiczna_pop.pdf (dostęp: 2.05.2020). 